conspicuous members of a rich Rhizopodal fauna), some were taken at from 15 to 20 fathoms, namely, Quinqueloculina agglutinans, Q. pulchella, Orbiculina compressa, and $O$. adunca; some at from 50 to 100 fathoms, namely, Orbiculina compressa, Dentalina acicula, and Orbitolina vesicularis; and several others at from 100 to 250 fathoms, namely, Dentalina acicula, D. communis, Cristellaria rotulata, C. cultrata, C. calcar, Frondicularia complanata, Amphistegina vulgaris, Polytrema miniacea, Bigenerina nodosaria, Verneuilina tricarinata, Textularia trochus, $T$. Barrettii, Cuneolina pavonia, Lituola scorpiarus, and $L$. Soldanii.

Cuneolina, a rare form, hitherto known only by figures, and description given by D'Orbigny, proves (as suspected) to be a modification of Textularia; and T. Barrettii is intermediate between it and Textularia proper. The Frondicularice are remarkably large and beautiful; and the Cristella,ice and Dentalina are also Jarge and relatively abundant.

This fauna is almost identical with the fossil Foraminifera of the Tertiary "Pteropod-marl" of Jamaica, above mentioned, specimens from which also were given by the late Mr. Barrett in $\mathbf{1 8 6 2}$ to the authors of this notice.

\title{
ON THE BIVALVED ENTOMOSTRACA OF THE CARBONIFEROUS STRATA OF GREAT BRITAIN AND IRELAND.
}

By Professon T. Rupent Jones, F.G.S., and J. W. Kirkby, Esq.

(Read before the British Association, at Newcastle, September, 1863.)

After a review of what former observers have published on the Bivalved Entomostraca of the Carboniferous formations, the authors proceeded to point out-1st, a few rather doubtful Cyprides or Candona, from the coalmeasures. 2ndly, Cytheres; of which there are about eight species, chiefly from the coal-measures. 3rdly, Bairdic; about eight species, mostly from the mountain-limestone and its shales. 4thly, Cypridinida; comprising Cypridina, Cypridella, Cyprella, Entomoconchus, and Cytherella, from the mountain-limestone; a fine collection of these rare forms from Little Island, Cork, liberally placed at Messrs. Jones and Kirkby's disposal by Mr. Joseph Wright, well elucidate the relationships of these hitherto obscure genera and their species. 5thly, Leperditidae; comprising Leperditia (to which genus belong the so-called Cypris Scotoburdigalensis, C. inflata, C. subrecta, Cythere inornata, and others; many of them dwarf varieties of one species, and mostly belonging to the mountain-limestone series); Entomis (mountain-limestone), Devonian and Carboniferous forms of which have been mistaken for Cypridina; Beyrichice (from nearly all parts of the Carboniferous system), several species, of which $B$. areuata, Bean sp., is the most common; and Firkbyo, somewhat rare, and chiefly from the mountain-limestone series.

Leperditia and Beyrichia are also Silurian and Devonian genera; they do not appear to pass upwards into the Permian formation. Bairdia and Kirkbya wecur first in the Carboniferous, and reappear in the Permian deposits, even in the same specifie forms; and Bairdia has been freely represented in Secondary and Tertiary deposits, and exists at present. Of the Cypridinidae under notice, Cypridella, Cyprella, and Entomoconchus appear to be confined to the mountain-limestone; Cypridina occurs in the Permian, and with Cytherella is found in Secondary and Tertiary rocks, and in ęxisting seas. Entomis is a Silurian and Devonian genus, especially characterizing the so-called "Cypridinen-Schiefer" of Germany. 